\title{
PKM PENGOLAHAN AIR BERSIH DENGAN PROTOTIPE SPL UPFLOW DI DESA KAYUWATU KECAMATAN KAKAS
}

\author{
Lolowang Jimmy \\ Jurusan Fisika FMIPA Universitas Negeri Manado \\ email : jimmylolowang@yahoo.com
}

\begin{abstract}
ABSTRAK
Air bersih merupakan salah satu komponen penting untuk kebutuhan hidup manusia. Air bersih digunakan untuk air minum, memasak, mandi maupun mencuci. Di Indonesia, untuk kebutuhan rumah tangga penduduk di pedesaan memerlukan air sebanyak 60-100 liter/hari/jiwa, sedangkan di perkotaan sedikit lebih banyak, $100 \mathrm{~s} / \mathrm{d} 150$ liter/hari/jiwa. Salah satu teknik pengolahan air yang sudah cukup lama dikenal dan masih banyak digunakan sekarang adalah saringan pasir lambat (SPL). Pada SPL air mengalir dari lapisan pasir halus di bagian atas menuju lapisan pasir kasar di bagian bawah dan selanjutnya ke lapisan kerikil di bagian paling bawah. Permasalahan yang sering terjadi pada SPL adalah karena sering terjadinya kebuntuan akibat kekeruhan air baku yang tinggi pada lapisan atasnya, akibatnya lapisan atas harus dikeruk atau dibersihkan. Namun demikian hal ini dapat ditanggulangi dengan cara modifikasi disain dengan menggunakan proses SPL upflow yakni penyaringan dengan aliran dari bawah ke atas. Pelatihan pembuatan prototipe SPL Upflow dalam pengolahan air bersih di Desa Kayuwatu Kecamatan Kakas Kabupaten Minahasa merupakan salah satu alternatif mengatasi permasalahan air bersih.
\end{abstract}

Kata kunci: Air bersih, prototipe SPL Upflow 


\section{PENDAHULUAN}

Air bersih merupakan salah satu komponen penting untuk kebutuhan hidup manusia. Air bersih digunakan untuk air minum, memasak, mandi maupun mencuci. Di Indonesia, untuk kebutuhan rumah tangga penduduk di pedesaan memerlukan air sebanyak 60-100 liter/hari/jiwa, sedangkan penduduk di perkotaan menggunakan air yang lebih banyak lagi, yaitu $100 \mathrm{~s} / \mathrm{d} \quad 150$ liter/hari/jiwa. Seiring dengan pertambahan penduduk, kebutuhan air pun semakin bertambah. Sayangnya pemenuhan kebutuhan air bersih saat ini sudah mulai berkurang, karena penurunan kualitas maupun kuantitas air bersih di lingkungannya. Penurunan kualitas air dapat disebabkan oleh adanya pencemaran air. Akibat yang ditimbulkan oleh pencemaran air menjadi masalah yang besar. Dampak dari pencemaran air yakni degradasi air bersih, baik air tanah, air sungai, maupun air laut (Achmad, 2004).

Menurut Johnstone dan Wood dalam Mungkasa (2006) bahwa masyarakat yang tidak dapat mengakses air bersih harus menanggung konsekuensi berupa tingginya biaya dan konsumsi air bersih menurun. Sebagai dampak tingginya biaya, jarak yang jauh dan waktu yang lama untuk mendapatkan air bersih menjadikan masyarakat tidak dapat memenuhi kebutuhan standar air bersih, yang berlanjut pada hilangnya pendapatan karena turunnya produktivitas dan bertambahnya biaya kesehatan.

Sementara itu teknologi untuk pengolahan air bersih yang ada sekarang sangat beraneka ragam, dari yang sederhana sampai dengan yang menggunakan teknologi canggih, dari yang biaya murah sampai yang mahal. Untuk memanfaatkan teknologi pengolahan air baku menjadi air bersih, jelas memerlukan biaya. Namun demikian masih ada beberapa alternatif pengolahan air bersih secara tradisional dan sederhana yang dapat digunakan.

Salah satu teknik pengolahan air yang sudah cukup lama dikenal dan masih banyak digunakan sekarang adalah saringan pasir lambat (SPL). Sejak tahun 1800-an saringan pasir lambat sudah lama dikenal di Eropa. Saringan pasir lambat dibuat pertama kali oleh John Gibb di Paisley Skotlandia tahun 1804 dalam skala yang kecil. Kemudian pada tahun 1829 James Simpson membuat saringan pasir lambat dalam skala yang besar untuk perusahaan air Chelsea di Inggris (Birdi, 1979).

Pada SPL air mengalir dari lapisan pasir halus di bagian atas menuju lapisan pasir kasar di bagian bawah dan selanjutnya ke lapisan kerikil di bagian paling bawah. Permasalahan yang sering terjadi pada SPL adalah karena sering terjadinya kebuntuan akibat kekeruhan air baku yang tinggi pada lapisan atasnya, akibatnya lapisan atas harus dikeruk atau dibersihkan. Namun demikian hal ini dapat ditanggulangi dengan cara modifikasi disain dengan menggunakan proses SPL upflow yakni penyaringan dengan aliran dari bawah ke atas (Said dan Wahjono, 1999).

\section{METODE}

Metode dalam kegiatan pengabdian ini dengan melakukan pendampingan dan pelatihan bagi warga desa Kayuwatu. Prototipe SPL Upflow yang akan dibuat disesuaikan menurut skala kebutuhan keluarga (skala rumah tangga). Skema peralatan tersebut tergambar di bawah ini.

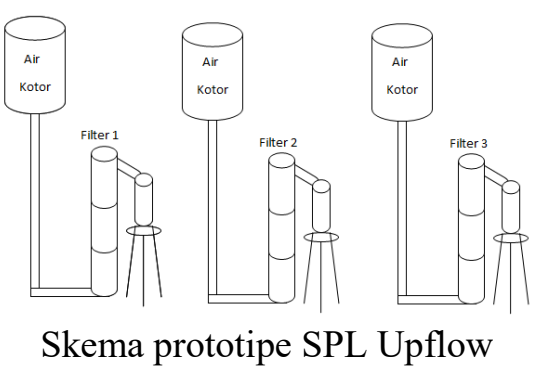

Keterangan :

Filter 1: menggunakan Ijuk/Sabut

Filter 2: menggunakan Pasir

Filter 3: menggunakan Arang

Dalam pembuatan peralatan prototipe SPL Upflow diperlukan alat dan bahan serta fungsinya sebagai berikut:

1. Wadah tempat penampungan air tercemar (air baku) sebanyak 2 buah Ember besar pakai penutup (volume 100 L). Kedua ember tersebut dihubungkan dengan pipa PVC ukuran 1 inci pada jarak $3 \mathrm{~cm}$ dari alas wadahnya. Pada wadah yang satunya di 
sisi lain dipasang pipa 1 inci yang dilengkapi dengan stop kran $3 / 4$ inci.

2. Wadah sedang untuk tempat filter dengan ketebalan $\mathrm{K} 1(20$ $\mathrm{cm}$ ) (tinggi: $25 \mathrm{~cm}$, diameter alas: $24 \mathrm{~cm}$, diameter penutup: $28 \mathrm{~cm}$, volume 10 liter) sebanyak 3 buah, yakni penutup berwarna hijau, merah dan biru. Wadah dengan penutup berwarna hijau untuk filter F1 (Sabut/ljuk), wadah dengan penutup berwarna merah untuk filter F2 (Pasir) dan wadah dengan penutup berwarna biri untuk filter F3 (Arang). Pada jarak $1 \mathrm{~cm}$ dari setiap alas wadah tersebut dibuat lubang dengan diameter sebesar $0,5 \mathrm{~cm}$ yang nanti akan dihubungkan dengan selang berdiameter $0,5 \mathrm{~cm}$. Pada jarak $1 \mathrm{~cm}$ dari bagian atas di sisi sebelahnya dari wadah dipasang stop kran $1 / 2$ inci

3. Wadah besar untuk tempat filter dengan ketebalan K2 $(40 \mathrm{~cm})$ (tinggi: $45 \mathrm{~cm}$, diameter alas: $28 \mathrm{~cm}$, diameter penutup:

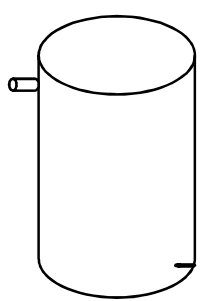
$28 \mathrm{~cm}$, volume 25 liter) sebanyak 3 buah, yakni penutup berwarna hijau, merah dan biru. (Mirip dengan wadah sedang untuk K1). Wadah dengan penutup berwarna hijau untuk filter F1

(Sabut/Ijuk), wadah dengan penutup berwarna merah untuk filter F2 (Pasir) dan wadah dengan penutup berwarna biri untuk filter F3 (Arang). Pada jarak $1 \mathrm{~cm}$ dari setiap alas wadah tersebut dibuat lubang dengan diameter sebesar $0,5 \mathrm{~cm}$ yang nanti akan dihubungkan dengan selang berdiameter $0,5 \mathrm{~cm}$. Pada jarak $1 \mathrm{~cm}$ dari bagian atas di sisi sebelahnya dari wadah dipasang stop kran $1 / 2$ inci .

4. Wadah tempat penampungan air setelah filtrasi untuk filter K1 (volume 5 liter) pakai penutup sebanyak 3 buah.

5. Wadah tempat penampungan air setelah filtrasi untuk filter K2 (volume 8 liter) pakai penutup sebanyak 3 buah.

6. Pipa paralon 1 inci, panjangnya $2 \mathrm{~m}$ yang pada ujungnya telah dipasang stop kran yang dihubungkan dengan wadah penampugan air baku. Pada pipa tersebut dibuat lubang dengan diameter sebesar $0,5 \mathrm{~cm}$ sebanyak 7 buah, yang masing-masing berjarak $25 \mathrm{~cm}$. Enam buah lubang dihubungkan masingmasing dengan selang berdiameter 0,5 $\mathrm{cm}$ ke inlet (lubang bagian bawah) wadah filter F1, F2 dan F3 baik K1 maupun $\mathrm{K} 2$, sedangkan lubang yang satunya dihubungkan dengan selang berdiameter $0,5 \mathrm{~cm}$ untuk pengambilan sampel air yang tidak melewati filter.

7. Pada bagian ujung dari tujuh buah selang yang disambungkan dari pipa paralon yang nantinya akan dihubungkan ke inlet filter, dipasang pipa kecil berdiameter $2 \mathrm{~mm}$ sedemikian rupa, sehingga debit air menjadi sebesar 2 liter/jam.

8. Pada stop kran outlet setiap filter (3 buah untuk K1 dan 3 buah untuk K2) juga dihubungkan dengan selang ke wadah bagian penampungan air hasil filtrasi (wadahnya tertutup).

9. Galon ukuran 25 liter sebanyak 6 buah untuk mengambil dan menampung air baku dari sumbernya, kemudian setelah tiba di lokasi terpasangnya peralatan dituangkan ke wadah penampungan air baku.

10. Meja tempat wadah penampungan (2 ember besar) setinggi $80 \mathrm{~cm}$.

11. Bangku setinggi $30 \mathrm{~cm}$, panjang 2 $\mathrm{m}$ untuk meletakkan 6 buah wadah filter, yakni filter F1 (Sabut/Ijuk), filter F2 (Pasir) dan filter F3 (Arang) dengan ketebalan filter $\mathrm{K} 1=20 \mathrm{~cm}$, filter $\mathrm{F} 1$ (Sabut/Ijuk), filter F2 (Pasir) dan filter F3 (Arang) dengan ketebalan filter K2 $=40 \mathrm{~cm}$.

12. Tiang penyanggah/Stand setinggi 1,5 m untuk menggantungkan pipa paralon 1 inci yang terhubung ke wadah penampungan.

13. Meja dan bangku diletakkan di bidang yang rata dan datar, selanjutnya pipa paralon disusun sedemikian rupa menggunakan waterpass (panjang 50 $\mathrm{cm}$ ) sehingga berada pada bidang datar.

14. Uji coba dilakukan dengan menggunakan air bersih untuk mengetahui kecepatan aliran pada setiap selang yang menuju ke inlet wadah filter maupun yang tanpa filter. Setelah semuanya berjalan lancar, peralatan sudah siap digunakan. 
B. Penyediaan Filter

Semua bahan alami yang digunakan sebagai filter yakni kerikil, sabut, ijuk, pasir sungai, pasir putih dan arang tempurung harus dibersihkan dan dicuci agar higienis. Pada bagian bawah dari setiap wadah untuk semua filter yang digunakan, ditempatkan kerikil dengan diameter $0,3-1,0 \mathrm{~cm}$, yang tebalnya sekitar $2 \mathrm{~cm}$, hal ini dimaksudkan untuk mengurangi resiko clogging. Kriteria penyediaan filter yaitu sebagai berikut:

1. Untuk wadah dengan penutup berwarna hijau diisi dengan filter F1 (Sabut/Ijuk). Perbandingan Sabut dan Ijuk yakni 1:1 dimana pada bagian bawah diletakkan filter sabut sedang bagian atas filter ijuk. Filter sabut diambil dari kelapa tua yang telah kering, selanjutnya diambil bagian yang lembut dengan membuang remah-remah yang ada. Sedang untuk ijuk digunakan bagian yang lembut, bagian serat dengan diameter kurang $1,0 \mathrm{~mm}$, lalu bagian lidinya dibuang. Sabut dan ijuk yang akan digunakan telah dicuci dan dijemur di panas matahari sehingga higienis

2. Untuk wadah dengan penutup berwarna merah diisi dengan filter F1 (Pasir). Pasir yang digunakan ada dua jenis, pada bagian bawah wadah filter diisi pasir sungai (berwarna hitam) dengan diameter $0,5-1,5 \mathrm{~mm}$, sedangkan pada bagian atas diisi pasir putih (silika) berdiameter kurang dari 1 $\mathrm{mm}$, dengan perbandingannya $1: 1$.

3. Untuk wadah dengan penutup berwarna biru diisi dengan filter F3 (Arang). Arang yang digunakan adalah arang tempurung. Ukuran arang yang digunakan ada dua macam, pada bagian bawah wadah diisi dengan arang yang berdiameter $3 \mathrm{~mm}-15$ $\mathrm{mm}$, sedangkan pada bagian atas diisi dengan arang berdiameter kurang dari $2 \mathrm{~mm}$, dengan perbandingannya $1: 1$.

\section{HASIL KAJIAN DAN PEMBAHASAN PEMBUATAN PROTOTIPE}

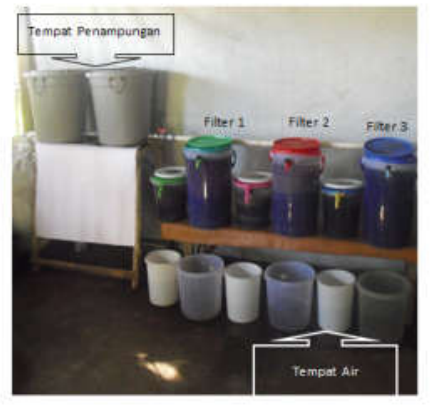

\section{KESIMPULAN}

Prototipe SP Upflow skala rumah tangga dapat dimanfaatkan untuk mengolah air kotor menjadi air bersih

\section{DAFTAR PUSTAKA}

Achmad, Rukaesih. 2004. Kimia Lingkungan. Andi Offset. Yogyakarta.

Birdi, 1979, http://kesehatanlingkunganindonesia.blogspot.com/ 2013/01/saringan-pasirlambat.html.

Karden, E.S.M. 2009. Pengelolaan Lingkungan Hidup. Djambatan. Jakarta

Mungkasa, Osmar. 2006. Pembangunan Air Minum dan Kemiskinan. Jurnal Percik, Oktober 2006, hal.18-20

Said, Nusa Idaman dan Heru Dwi Wahjono, 1999, Teknologi Pengolahan Air Bersih Dengan Proses Saringan Pasir Lambat "Up Flow" (www.kelair.bppt.go.id/Publikasi/ Buku10Patek/03PASIR.pdf). 